\title{
JURNAL ECONOMAC
}

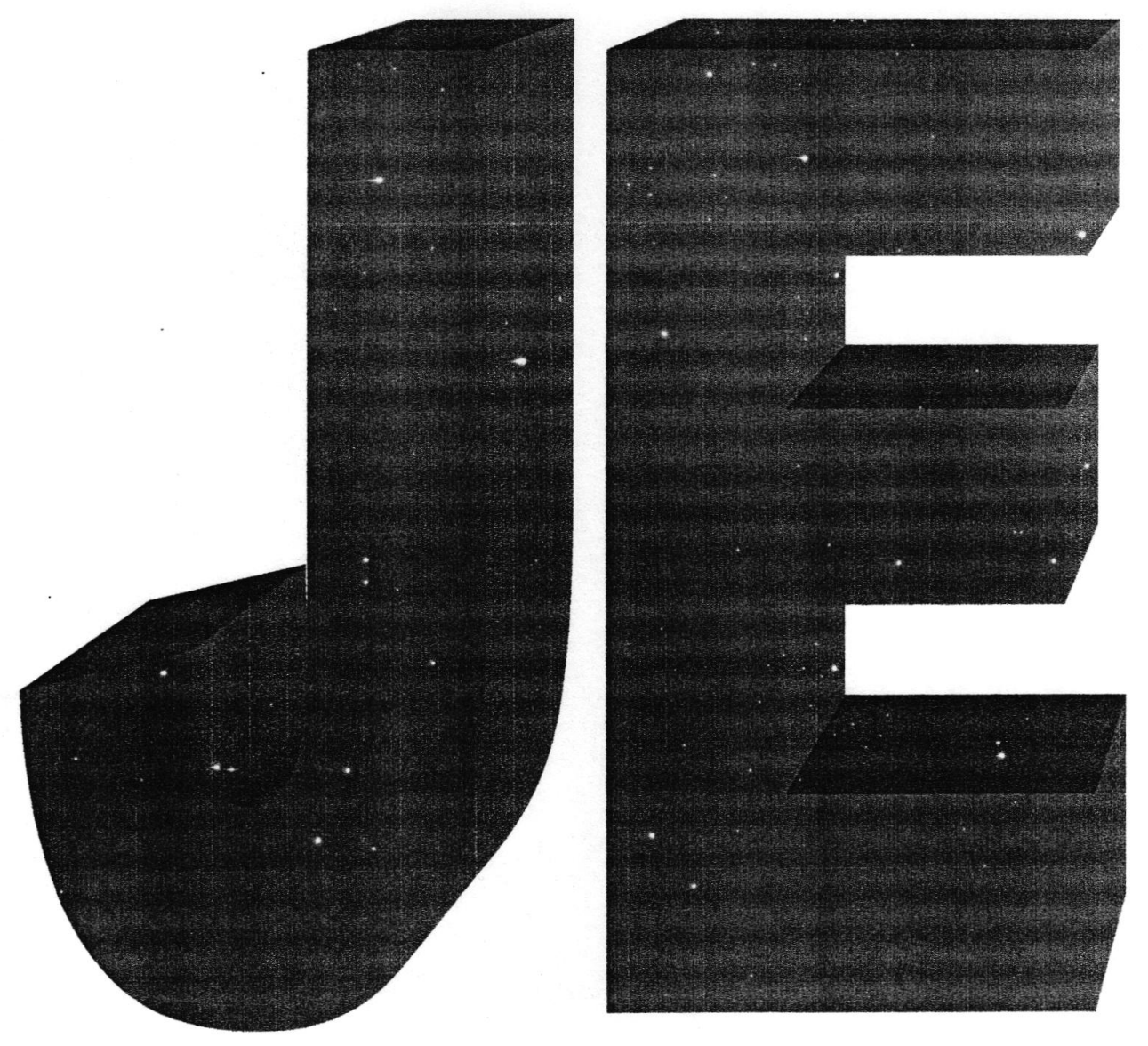

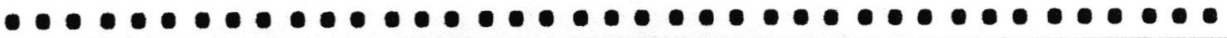

Diterbitkan oleh:

Fakultas Ekonomi

Universitas Negeri Padang

\begin{tabular}{|l|l|l|l|l|}
\hline $\begin{array}{l}\text { Jurnal } \\
\text { Economac }\end{array}$ & Volume 10 & Nomor 1 & $\begin{array}{l}\text { Padang } \\
\text { April 2010 }\end{array}$ & $\begin{array}{l}\text { ISSN } \\
1412-3290\end{array}$ \\
\hline
\end{tabular}




\title{
JURNAL ECONOMAC \\ ISSN 1412-3290 \\ Volume 10, Nomor 1, April 2010
}

\section{Penasehat}

Dekan Fakultas Ekonomi Universitas Negeri Padang

Penanggung Jawab

Pembantu Dekan I Fakultas Ekonomi Universitas Negeri Padang

\section{Ketua Penyunting}

Sulastri

Penyunting Ahli

Z.Mawardi Effendi (Universitas Negeri Padang)

Supriyanto (Universitas Malang)

Agus Irianto (Universitas Negeri Padang)

Edwardus Tande lilin (Universitas Gadjah Mada)

Diah Natalisa (Universitas Sriwijaya)

Bustari Mukhtar (Universitas Negeri Padang)

Mulyadi (Universitas Brawijaya)

Yasri (Universitas Negeri Padang)

\section{Penyunting Pelaksana}

\author{
Efrizal Syofian \\ Hasdi Aimon \\ Perengki Susanto \\ Joan Marta \\ Sany Dwita \\ Erly Mulyani \\ Irawati
}

\footnotetext{
Alamat Sekretariat Redaksi

Fakultas Ekonomi Universitas Negeri Padang

Jln.Prof.Dr.Hamka, Air Tawar Padang

Telp.(0751) 445089

Fax. (0751) 447366

Email: economac_feunp@gmail.com

Jurnal Economac Fakultas Ekonomi Universitas Negeri Padang
}

\footnotetext{
JURNAL ECONOMAC, diterbitkan sejak tanggal 21 Februari 2003 oleh Fakultas Ekonomi Universitas Negeri Padang, mulai Volume 7, Nomor 1, April 2007 Economac berubah format seperti yang ada sekarang dan terbit dua kali
dalam setahun (periode April dan Oktober)
} 


\section{JE \\ JURNAL ECONOMAC \\ ISSN 1412-3290 \\ Volume 10, Nomor 1, April 2010}

\section{DAFTAR ISI}

Specific Performance Measurement Instruments for Sourcing Strategy

Haim Hilman Abdullah (Universitas Utara Malaysia)

Pengaruh Ukuran, Umur, Likuiditas, Leverage, dan Aktivitas Perusahaan terhadap Profitabilitas

$11-18$

Pada Perusahaan Manufaktur yang Terdaftar di PT. Bursa Efek Indonesia (BEI).

Erly Mulyani dan Lili Anita (Universitas Negeri Padang)

Pelayanan dan Jasa-jasa Publik di Indonesia

Ariusni dan Vidyarini Dwita (Universitas Negeri Padang)

Pengaruh Antara Tingkat Kepercayaan Kemitraan dan Kesuksesan Kemitraan dengan

Manfaat Kemitraan pada Proyek Konstruksi di Provinsi Maluku

Fransiska Natalia Rahallo (Universitas Patimura Ambon)

Proses Audit pada Era Teknologi Informasi serta Implikasi terhadap Pembelajaran Auditing

Fefri Indra Arza (Universitas Negeri Padang)

Pengaruh Persepsi Guru tentang Kepemimpinan Kepala Sekolah dan Motivasi Berprestasi

Terhadap Kinerja Guru.

Akhirmen (Universitas Negeri Padang)

Faktor-faktor yang Mempengaruhi Kinerja Usaha Kecil Kerupuk Sanjai

Desi Susanti (Universitas Negeri Padang)

Green Marketing: Konsep Alternatif dalam Pemasaran

$65-72$

Abror (Universitas Negeri Padang)

Pemasaran Politik: Pendekatan Konseptual bagi Pelaku Politik

$73-79$

Perengki Susanto (Universitas Negeri Padang) 


\title{
GREEN MARKETING : KONSEP ALTERNATIF DALAM PEMASARAN
}

\begin{abstract}
Abror
Abstract : Green marketing is an alternative concept in marketing. Every marketers must concern about this, because of the situation has been changed. Customer now becoming smart and care about environmental issues. When the marketers want to sell product to the market, they should be aware with this. The marketers permitted to use one of two green marketing approaches. Defensive or Assertive approach, but if the marketers want to get a sustainable competitive advantage, they had better to use assertive approach. Green Marketing still has some constraints or problems in implementation, the marketer must give good education to the customers and make a good communication with them.
\end{abstract}

Kata Kunci: Green Marketing, environmental marketing, ecological marketing

Lingkungan pemasar mengalami perubahan yang sangat radikal, seperti perubahan teknologi, globalisasi dan peraturan pemerintah. Kondisi ini akan mendorong timbulnya perilaku baru dari konsumen yang tercermin pada kebutuhan dan keinginannya. Agar mampu memenangkan persaingan, pemasaran harus cepat bereaksi terhadap perubahan permintaan pelanggan dan memuaskan semua kebutuhan dan keinginan mereka, karena pada dasarnya pemasaran berhulu dan bermuara pada pelanggan.

Akhir-akhir ini kesadaran masyarakat terhadap lingkungan hidup mulai meningkat setelah melihat banyaknya kerusakan lingkungan yang terjadi. Organisasi pemerhati lingkungan mulai bermunculan dan mengkritisi aktivitas yang dilakukan oleh pemasar. Hal ini mempengaruhi konsumen sehingga mereka mulai menaruh perhatian pada isu lingkungan hidup lebih dari pada sebelumnya. Konsumen menjadi sangat perhatian terhadap keterbatasan sumber daya yang ada di bumi, kesehatan dan perusakan lingkungan, sehingga mulai melirik produk yang lebih bertanggungjawab kepada lingkungan. Sejalan dengan itu, pemerintah mulai mengeluarkan peraturan yang berhubungan dengan lingkungan.

Perubahan ini menimbulkan tantangan yang harus dijawab bagi pemasar berupa peluang atau ancaman. Pemasar yang pintar akan memandang isu lingkungan hidup sebagai peluang untuk memuaskan kebutuhan dan keinginan konsumen, bukan ancaman. Pemasar akan mengaplikasikan isu lingkungan dalam aktivitas pemasaran yang mereka lakukan, sehingga menimbulkan fenomena baru dalam dunia pemasaran berupa konsep Green Marketing.

\section{GREEN MARKETING}

Melaksanakan konsep green marketing dalam suatu perusahaan berarti memasukkan per-timbangan lingkungan dalam semua dimensi akti-vitas pemasaran yang dilakukan perusahaan (Crane, 2000). Dalam literatur yang ada, konsep green marketing merupakan variasi terminologi dari environmental marketing, ecological marketing, green marketing, sustainable marketing, greener marketing (Prakash, 2002), dan societal marketing (Kotler 2003).

Sebenarnya konsep green marketing bukanlah hal yang baru. Konsep ini sudah diperkenalkan oleh Bell dan Emeri, serta Feldman sejak tahun 1971, yang menyatakan konsep pemasaran telah salah penempatan, karena hanya sebatas me-muaskan keinginan konsumen tapi dengan meng-abaikan kepentingan masyarakat dan lingkungan dalam jangka panjang (MCDaniel dan Rylander, 1993).

Pada tahun 1976 Henion dan Kinnear memperkenalkan ecological marketing sebagai ilmu yang mempelajari dampak positif dan negatif dari aktivitas pemasaran pada polusi, penipisan energi dan dan penipisan sumberdaya non energi (Polonsky, 1994). Pengertian ini digunakan dalam workshop yang diadakan oleh The American Marketing association (AMA) yang melibatkan akademisi, praktisi dan pembuat keputusan publik. 
Kotler pada tahun 1976 kemudian memperkenalkan konsep societal marketing untuk memenuhi tanggung jawab sosial pemasar yang terdiri dari empat pertimbangan dalam pengambilan keputusan pemasaran yaitu : keinginan konsumen, kepentingan konsumen, persyaratan perusahaan, dan kesejahteraan lingkungan sosial. (MC.Daniel dan Rylander, 1993). Konsep ini menyatakan bahwa tugas organisasi adalah menentukan kebutuhan, keinginan, dan kepentingan dari pasar sasaran, dan memberikan kepuasan secara lebih efektif dan efisien dibandingkan dengan pesaing dengan jalan melindungi atau meningkatkan kesejahteraan konsumen dan masyrarakat (Kotler, 2003)

Peattie pada tahun 1995 mendefinisikan green marketing sebagai proses manajemen holistik yang bertanggung jawab untuk mengidentifikasi, mengantisipasi dan memuaskan keinginan konsumen dan masyarakat dengan jalan yang menguntungkan dan berkelanjutan (Karna, Hansen dan Juslin 2001).

Sementara Polonsky (1994), menyatakan bahwa green marketing merupakan seluruh aktivitas yang didesain untuk menghasilkan dan memfasilitasi semua perubahan yang diharapkan dapat memuaskan kebutuhan dan keinginan manusia, dengan dampak minimal pada perusakan lingkungan alam. Hal ini terjadi akibat pemenuhan kebutuhan dan keinginan manusia memiliki potensi untuk menimbulkan dampak negatif pada lingkungan alam.

Dari pengertian-pengertian ini dapat disimpulkan bahwa green marketing mengandung beberapa poin penting yaitu: pertama organisasi atau perusahaan melalui aktivitas pemasarannya berusaha memuaskan kebutuhan dan keinginan konsumen, kedua aktivitas pemasaran ini dilaksanakan dengan cara yang lebih efisien dan efektif disbandingkan dengan pesaing, dan ketiga aktivitas ini memberikan dampak minimal pada perusakan lingkungan alam sehingga dapat meningkatkan kesejahteraan konsumen dan masyarakat.

\section{PENTINGNYA GREEN MARKETING}

Green marketing merupakan konsep yang makin menarik bagi akademisi, praktisi, pembuat aturan publik, konsumen serta masyarakat yang peduli terhadap lingkungan. Alasan mengapa konsep ini menjadi sangat penting untuk diaplikasikan oleh perusahaan merupakan alasan sederhana yang sudah diketahui sejak dahulu, yaitu keterbatasan sumberdaya.
Dalam literatur ekonomi dinyatakan, bahwa ilmu ekonomi adalah ilmu yang mempe-lajari bagaimana manusia memenuhi kebutuhan dan keinginannya dengan alat pemenuhan kebutuh-an atau sumber daya yang terbatas. Sumberdaya yang ada didunia, baik sumberdaya alam ataupun bukan, jumlahnya terbatas. Eksploitasi sumberdaya yang semena-mena dapat menyebabkan kerusakan lingkungan yang pada akhirnya menurunkan kesejahteraan konsumen dan masyarakat.

Dari sudut pandang pemasar sendiri, keterbatasan sumberdaya membuat perusahaan mencari cara baru untuk memenuhi kebutuhan dan keingin-an konsumen. Konsep green marketing merupakan suatu alternatif yang dapat digunakan pemasar da-lam melaksanakan aktivitas pemasaran dengan memanfaatkan sumberdaya yang terbatas secara efi-sien dan efektif. Menurut Bath (1993) green mar-keting dimulai dengan green design, dan untuk da-pat melaksanakannya dengan lebih baik perusaha-an dapat membentuk green value chain atau meng-gunakan strategi aliansi (Mendelson et all 1995).

\section{Faktor Pendorong Green Marketing}

Menurut Bansal dan Kendal (2000) faktor pendorong perusahaan untuk lebih memperhatikan lingkungan adalah peraturan pemerintah (legislation), tekanan stakeholder (stakeholder pressures), kesempatan ekonomi (economic opportunities), dan motif etis (ethical motives).

Sementara menurut Polonsky (1994) ada lima alasan bagi organisasi atau perusahaan untuk menerapkan konsep green marketing. Pertama organisasi dapat menggunakan konsep green marketing untuk memanfaatkan peluang dalam men-capai tujuannya. Kedua organisasi percaya bahwa mereka memiliki kewajiban moral untuk lebih bertanggungjawab secara sosial. Ketiga Badan pemerintah melalui peraturan yang dikeluarkannya memaksa perusahaan untuk lebih bertanggung jawab terhadap lingkungan. Keempat aktivitas lingkung-an yang dilakukan pesaing memaksa perusahaan untuk merubah aktivitas pemasaran lingkungan mereka. Terakhir adalah faktor biaya yang di-asosiasikan dengan pemborosan pembuangan, atau mengurangi penggunaan material yang membuat perusahaan merubah perilaku mereka.

\section{Faktor Peluang}

Meningkatnya kesadaran konsumen terhadap lingkungan alam menimbulkan perubahan dalam perilaku pembelian mereka. Konsumen 
menjadi lebih sensitif dalam pemilihan produk yang akan mereka konsumsi. Mereka akan memilih produk ramah lingkungan yang ditawarkan oleh pemasar.

Konsumen yang sangat menyadari arti pentingnya lingkungan alam bahkan mau membeli pada harga premium, tentu saja dengan tidak mengabaikan kualitas. Sehingga pemasar menganggap hal ini merupakan peluang yang baik untuk memenangkan persaingan dan mencapai tujuan perusahaan. Sebagai contoh McDonald menukar kemasan masakan kerangnya dengan kertas lilin (waxed paper) karena meningkatnya perhatian konsumen terhadap produksi polisterin dan penipisan ozon.

Xerox memperkenalkan kertas fotocopy berkualitas tinggi dari proses daur ulang untuk memenuhi keinginan konsumen terhadap perusakan lingkungan yang seminimal mungkin. Perusahaan pengalengan Tuna memodifikasi tekhnik penangkapan ikan mereka karena meningkatnya perhatian masyarakat dan konsumen terhadap kematian lumbalumba.

\section{Faktor Tanggung Jawab Sosial}

Banyak perusahaan yang mulai menyadari bahwa mereka sendiri merupakan bagian dari komunitas yang luas dan untuk itu mereka harus memiliki perhatian terhadap lingkungan. Mereka percaya bahwa tujuan mereka untuk menjaga kelestarian lingkungan akan sejalan dengan tujuan perusahaan untuk menghasilkan keuntungan. Sebagai hasilnya isu lingkungan akan terintegrasi dengan budaya perusahaan secara keseluruhan.

Perusahaan dalam hal ini bisa memilih dua alternatif perspektif yang akan digunakannya. Pertama perusahaan mengkomunikasikan kepedulian mereka terhadap lingkungan hidup kepada konsumen dan masyarakat sebagai alat pemasaran. Kedua perusahaan bertanggung jawab pada lingkungan hidup tanpa mempromosikannya. Sebagai contoh Bodyshop dengan gencar mempromosikan bahwa mereka bertanggungjawab terhadap lingkungan dengan sedapat mungkin menggunakan sayuran sebagai bahan dasar kosmetiknya dibandingkan penggunaan hewan, tidak menggunakan binatang untuk menguji produk akhirnya, menghargai lingkungan, menggunakan bahan dasar yang alami serta konsumen dapat membeli sesuai dengan kuantitas yang mereka inginkan dan menggunakan kemasan isi ulang. Bodyshop mengguna- kan kepeduliannya terhadap lingkungan sebagai competitive advantage dimana filosofi dari kepedulian terhadap lingkungan tercermin pada budaya perusahaan. Sementara Coca-cola melakukan investasi dalam jumlah yang besar pada aktivitas daur ulang, dan memodifikasi kemasannya untuk meminimalisasi dampak terhadap lingkungan tanpa mengkomunikasikan dan menggunakanya sebagai alat pemasaran.

\section{Faktor Tekanan Pemerintah}

Sehubungan dengan seluruh aktivitas pemasaran yang dilaksanakan perusahaan, pemerintah berusaha melindungi konsumen dan masyarakat, melalui peraturan yang ditetapkan. Peraturan pemerintah ini didesain untuk melindungi konsumen dengan jalan mengurangi produksi produk yang merusak lingkungan, mengubah perilaku konsumen dan industri dalam penggunaan atau mengkonsumsi produk yang merusak lingkungan, dan meyakinkan konsumen kalau mereka memiliki kemampuan untuk menilai produk terkait dengan pemeliharaan lingkungan hidup. Peraturan ini mengimplikasikan penerapan konsep green marketing bagi perusahaan.

Perusahaan akan berusaha mematuhi peraturan yang ditetapkan pemerintah untuk tetap bertahan dalam bisnis. Peraturan mengenai lingkungan hidup di Indonesia didasarkan pada UndangUndang Pengelolaan Lingkungan Hidup no 23 tahun 1997. Salah satunya adalah Peraturan Pemerintah Republik Indonesia nomor 4 tahun 2001 tentang pengendalian kerusakan dan atau pencemaran lingkungan hidup yang berkaitan dengan kebakaran hutan dan atau lahan. Bagi pihak yang melakukan pelanggaran terhadap undang-undang dan peraturan ini dapat dikenakan sanksi.

\section{Faktor Persaingan}

Alasan utama lainnya untuk melaksanakan konsep green marketing adalah untuk menjaga posisi perusahaan dalam persaingan. Perusahaan mulai melihat pesaing mempromosikan perilaku yang ramah lingkungan, dan ini bisa membahayakan kedudukan perusahaan dalam persaingan. Oleh sebab itu, perusahaan berusaha untuk menyamai atau bahkan melebihi pesaing dalam menerapkan konsep green marketing. Dalam hal lain tekanan persaingan menyebabkan beberapa perusahaan 
memodifikasi dan mengurangi perilaku yang merusak lingkungan.

\section{Faktor Biaya atau Keuntungan}

Perusahaan juga menggunakan konsep green marketing untuk dapat mengurangi biaya dan atau meningkatkan kemampuannya dalam menghasilkan laba. Perusahaan yang dapat mengurangi limbah yang dihasilkan dari proses industrinya bisa menghemat biaya. Biasanya minimalisasi limbah dilakukan dengan jalan menguji kembali proses produksi yang dilakukan. Hasilnya sering juga meningkatkan keefektifan proses produksi itu sendiri. Sehingga terdapat penghematan biaya berganda yaitu mengurangi limbah dan menghemat material.

Dalam beberapa situasi, perusahaan dapat mencari pasar untuk produk sampingan, pembuangan atau limbah yang mereka hasilkan, sehingga dapat meningkatkan pendapatan perusahaan. Selain itu isu green marketing dapat mendorong berkembangnya industri baru. Hal ini bisa terjadi melalui dua cara, pertama tumbuhnya perusahaan yang mengembangkan teknologi untuk mengurangi pemborosan dan menjualnya pada perusahaan lain. Kedua berkembangnya industri daur ulang dan pembuangan.

\section{Pendekatan Perusahaan Dalam Green Marketing}

Menurut McDaniel dan Rylander (1993) terdapat dua pendekatan dasar dalam green marketing yaitu defensive atau reactionary approach dan assertive atau aggressive strategy.

\section{Pendekatan Defensif}

Pendekatan defensif merupakan pendekatan dimana perusahaan hanya melakukan konsep green marketing dalam proporsi yang paling minimal untuk menghindari konsekuensi negatif yang bisa saja dihadapi perusahaan. Pendekatan inilah yang paling banyak digunakan oleh perusahaan yang mengadopsi konsep green marketing saat ini.

Ada tiga tipe pendekatan defensif yang lazim digunakan perusahaan. Pertama perusahaan hanya memenuhi standar minimum dari peraturan pemerintah terhadap lingkungan untuk meng- hindari sanksi seperti pembayaran pajak yang lebih tinggi atau denda. Kedua adalah perusahaan akan memenuhi standar minimum kepedulian terhadap lingkungan guna menghindari pemboikotan produk atau perusahaan oleh konsumen. Terakhir dari tipe pendekatan defensif adalah perusahaan yang bereaksi terhadap perubahan perilaku kompetitor pada lingkungan, dan mecoba meniru perilaku ini, namun dalam pelaksanaannya masih kurang dari yang seharusnya dapat mereka lakukan.

Strategi ini pada dasarnya tidak dapat menghasilkan peningkatan yang signifikan terhadap penerimaan pasar. Image perusahaan dimata konsumen tidak akan lebih baik dibandingkan pesaing, sebab konsumen mengetahui bahwa usaha perusahaan untuk peduli terhadap lingkungan masih dalam taraf yang rendah. Secara umum perusahaan yang masih belum memenuhi standar-standar lingkungan hidup tidak dapat menjadikan dimensi ini sebagai competitive advantage, dan lebih rentan terhadap reaksi negatif dari pelanggan atau pemerintah. Marc Gobe, direktur kreatif pada Cato Gobe, meramalkan bahwa perusahaan yang tidak memperhatikan isu lingkungan akan meng-hadapi penurunan pangsa pasar ( Mill dalam Mc-Daniel dan Rylander 1993 )

\section{Pendekatan Assertif}

Pendekatan assertif merupakan pendekatan dimana perusahaan merupakan pelopor atau first mover dalam penerapan konsep green marketing. Aktivitas pemasaran yang dilakukannya melebihi dari apa yang syaratkan oleh pemerintah atau yang diminta oleh konsumen. Pendekatan ini merupakan peluang yang baik untuk mendapatkan sustainable competitive advantage.

Perusahaan yang menggunakan pendekatan assertif berarti lebih mengutamakan respon terhadap permintaan konsumen, dibandingkan untuk memenuhi peraturan pemerintah. Menurut Wells (McDaniel dan Rylander, 2001) pendekatan green marketing yang merespon permintaan pasar adalah perusahaan yang berorientasi pada konsumen dan profit driven.

First mover atau pelopor memiliki beberapa keunggulan penting dalam green marketing. Pertama meningkatnya image perusahaan dimata konsumen. Jika perusahaan dapat mem- 
pertahankan image ini, maka akan tercipta sustain-able competitive advantage. Image yang baik merupakan kunci dalam meningkatkan profit-abilitas. Perusahaan lain yang mengikuti langkah first mover akan dianggap sebagai imitator yang hanya berada dibelakang perusahaan pelopor. Konsumen bisa jadi bersikap skeptis terhadap perusahaan yang terlambat dalam memenuhi keinginan mereka.

Keunggulan yang kedua adalah dapat menghindari pemeriksaan dan mentaati peraturan dengan melakukan aktivitas green marketing melebihi yang disyaratkan pemerintah. Agen pemerintahan tidak akan melakukan penyelidikan atau pengawasan terhadap perusahaan yang melaksanakan tindakan peduli lingkungan melebihi standar yang ditetapkan.

Sebagai tambahan perusahaan yang meng-gunakan pendekatan assertif terikat pada pe-rencanaan jangka panjang terhadap lingkungan. Hal ini membuat perusahaan lebih fokus pada tu- juan jangka panjang yang sangat penting dalam perusahaan. Sementara perusahaan lain mungkin mengalami kesulitan dalam menentukan tujuan jangka panjangnya karena terfokus pada tujuan jangka pendek.

\section{Green Marketing dan Pengembangan Strategi Pemasaran}

Memasukkan green marketing pada proses perencanaan strategi seringkali menimbulkan permasalahan dalam perusahaan, karena kebijakan terhadap lingkungan hanya diperlakukan sebagai tambahan bukan diintegrasikan secara penuh dalam sebuah perencanaan strategis. Perusahaan seharusnya mendesain sebuah proses perencanaanl pemasaran strategis dengan green marketing sebagai bagian yang terintegrasi secara penuh. Gambar 1 menggambarkan model untuk melaksanakannya

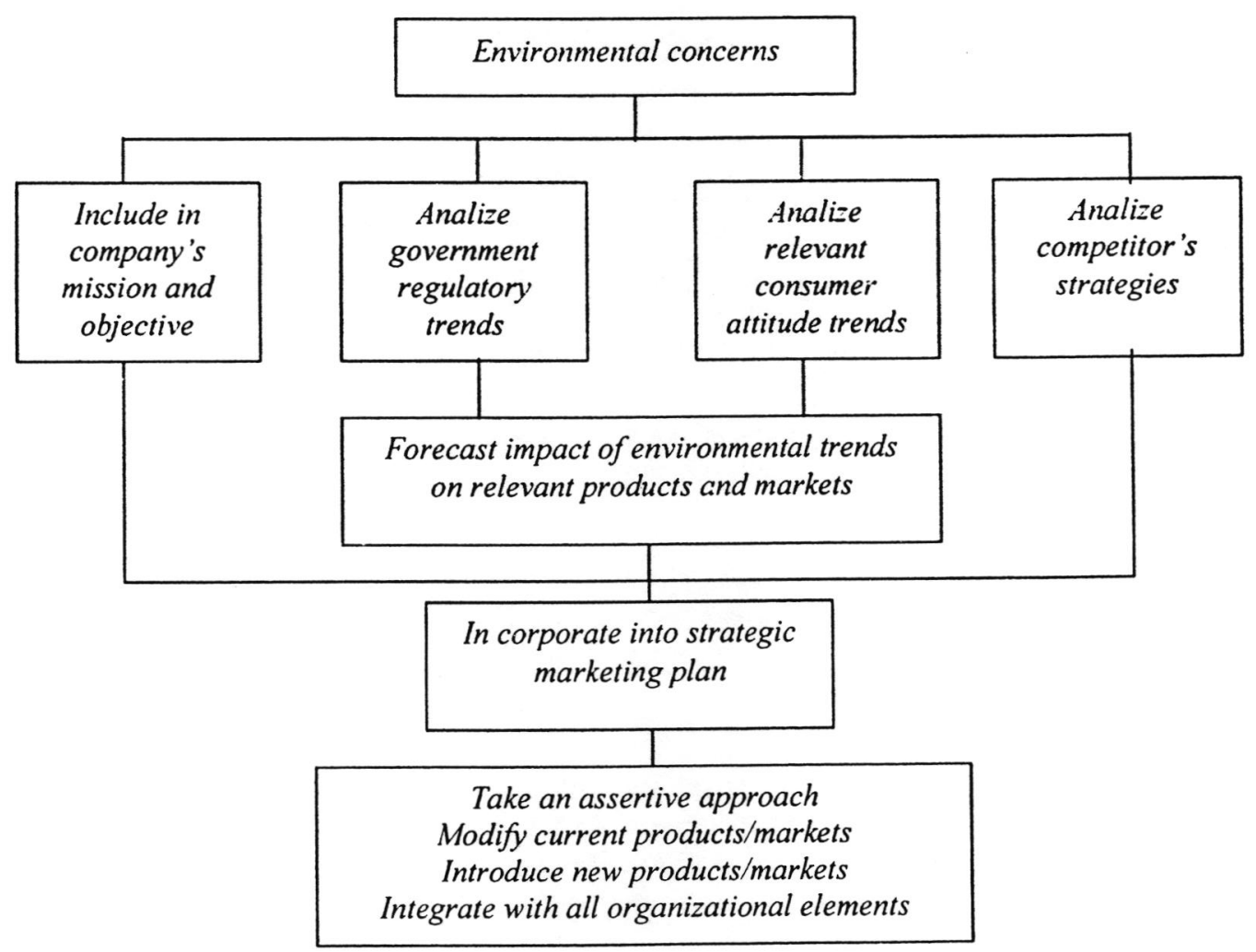

Gambar 1. Model Green Marketing

Sumber: McDaniel and Rylander 1993 
Untuk mempermudah dan menfasilitasi proses ini dapat dilakukan sepuluh langkah berikut (McDaniel and Rylander 1993) : (1). Mengembangkan sebuah kebijakan perusahan terhadap lingkungan, (2) Membangun kepemimpinan lingkungan pada level atas organisasi, (3) Menyewa atau mengembangkan pengacara lingkungan pada perusahaan, (4) Melakukan pendidikan dan pelatihan seluruh karyawan organisasi untuk menciptakan kesadatran terhadap lingkungan, (5) Menjalin komunikasi yang aktif dengan kelompok lingkungan hidup diluar perusahaan dan agen pemerintahan, (6) Mengembangkan program tindakan assertif terhadap lingkungan, (7) Mengintegrasikan seluruh departemen untuk menfasilitasi fleksibilitas dalam merespon kebutuhan yang berhubungan dengan lingkungan, (8) Mengalokasikan sumberdaya yang terbatas untuk memperlihatkan komitmen, (9) Mengkomunikasikan tindakan yang dilakukan perusahaan melalui periklanan dan publisitas yang efektif, (10) Memonitor res-pon konsumen melalui program riset pemasaran aktif. Implementasi dari sepuluh langkah ini di dalam perusahaan, sangat membutuhkan pendidikan dan kominikasi yang intensif, baik secara internal maupun eksternal. Komunikasi eksternal melalui periklanan dan publisitas merupakan hal yang sangat penting. Perusahaan harus berhati-hati dalam melakukan komunikasi kepada konsumen, sehingga pesan yang diterima oleh konsumen sesuai dengan yang ingin disampaikan perusahaan.

Wells dalam McDaniel dan Rylander (1993) memberikan beberapa tip penting untuk mencapai kesuksesan dalam berkomunikasi yaitu: (1) Gambarkan komitmen perusahaan terhadap lingkungan dengan sungguh-sungguh , (2) Bersiaplah untuk diselidiki atau diperiksa oleh pihak lain, (3) Fokus pada tindakan positif tapi tetap berhati-hati terhadap munculnya penolakan dari pihak lain, (4) Buatlah pernyataan dengan sederhana dan mudah dimengerti.

\section{MASALAH DALAM MELAKSANAKAN GREEN MARKETING}

Dalam usaha mengaplikasikan konsep green marketing terdapat beberapa permasalahan potensial yang bisa muncul menurut Polonsky (1994). Pertama adalah perusahaan yang meng- gunakan green marketing harus yakin bahwa tindakan mereka tidak menyesatkan konsumen dan industri, dan tidak melakukan pelanggaran terhadap peraturan atau hukum yang berlaku pada pemasaran lingkungan. Penerapan green marketing menuntut adanya sosialisasi yang jelas kepada konsumen, setiap konsumen perlu di edukasi terlebih dahulu agar melakukan pilihan produk dengan memperhatikan faktor kepedulian terhadap lingkungan.

Masalah kedua yang dihadapi perusahaan adalah pada saat memodifikasi produk mereka sesuai permintaan ataupun persepsi konsumen, tapi ternyata produk ini juga tidak lebih baik dari produk yang terdahulu karena konsumen memeliki persepsi yang salah. Oleh sebab itu perusahaan harus memiliki pengetahuan yang baik sehingga dapat mengambil keputusan dan tindakan terhadap lingkungan yang benar. Produk yang tidak sesuai dengan selera konsumen akan sulit untuk dipilih oleh konsumen, terutama dalam era saat ini yang digerakan oleh pelanggan (customer driven).

Masalah ketiga adalah peraturan pemerintah yang didisain guna memberikan peluang kepada konsumen untuk membuat keputusan yang lebih baik, atau memotivasi mereka untuk lebih bertanggungjawab terhadap lingkungan hidup. Sangat sulit bagi perusahaan untuk dapat menyesuaikan dengan seluruh isu lingkungan. Oleh karena itu sebaiknya pemerintah mengembangkan aturan dan petunjuk yang jelas. Dalam penyusunan peraturan pemerintah juga perlu memperhatikan isu-isu yang berkembang di dunia internasional dan menyesuaikan diri dengan perubahan yang ada seperti penerapan ecolabelling ataupun penerapan label halal.

Bereaksi berdasarkan tindakan kompetitor dapat menyebabkan follower membuat kesalahan yang sama dengan first mover. Oleh karena itu perusahaan yang mengikuti langkah kompetitor harus lebih cermat dalam bereaksi terhadap tindakan kompetitornya.

\section{KESIMPULAN DAN SARAN}

\section{Kesimpulan}

Green Marketing merupakan sebuah konsep yang perlu diperhatikan oleh perusahaan 
dalam memasarkan produknya, hal ini dikarenakan semakin meningkatnya kesadaran konsumen akan pentingnya kepedulian terhadap lingkungan. Sebuah perusahaan dalam memasarkan produknya pada saat ini harus mulai berorientasi pada pemasaran yang ramah lingkungan yang dimulai dari pembuatan perencanaan strategis.

Dengan memasukan unsur kepedulian terhadap lingkungan secara terintegrasi dalam setiap perencanaan strategisnya, perusahaan akan mampu menjadikan hal tersebut sebagai salah satu sumber Sustainable Competitive Advantage yang bisa digunakan untuk memenangkan persaingan. Implikasi lain bagi perusahaan adalah, perusahaan bisa memilih salah satu diantara dua pendekatan dalam green marketing yaitu pendekatan defensive atau pendekatan assertif.

Dalam penerapan green marketing, terdapat potensi terjadinya masalah yang berasal dari: pertama kemungkinan terjadinya pelanggaran terhadap aturan yanga ada dalam penerapan green marketing, ke dua produk yang di modifikasi ternyata tidak mampu memberikan nilai tambah bagi konsumen, sehingga konsumen tetap menganggap tidak ada perubahan yang signifikan pada produk yang dihasilkan. Kemampuan perusahaan menyesuaikan diri dengan perubahan peraturan dan keinginan konsumen menjadi masalah ke tiga, terakhir jika perusahaan tidak berhati-hati menghadapi reaksi pesaing dalam penerapan green marketing, akan menyebabkan terjadinya kesalahan pengambilan keputusan.

\section{Saran}

Jika perusahaan ingin mendapatkan sebuah keunggulan yang mampu membuatnya berbeda dari pesaing dan sesuai dengan keinginan dan kebutuhan pelanggan, perusahaan sebaiknya lebih memilih pendekatan assertif yang mampu menciptakan image positif bagi perusahaan. Perusahaan yang menjadi first mover akan mendapatkan keunggulan dan selalu diingat untuk pertama kali. Perusahaan yang menerapkan pendekatan assertif lebih mengutamakan respon dari konsumen daripada permintaan pemerintah.

Dalam penerapan konsep green marketing, perusahaan akan mengalami beberapa kendala, oleh karena itu perusahaan harus mampu mengantisipasinya dengan beberapa cara seperti dengan memberikan pendidikan dan membangun komunikasi yang baik dengan setiap stakeholder yang terlibat. Kedekatan dengan pelanggan harus dijaga dengan baik, agar apa yang dilakukan oleh perusahaan, bisa diterima oleh pelanggan dan memberikan efek positif terhadap kinerja pemasaran perusahaan.

Perusahaan dimasa yang akan datang semakin dtuntut untuk melakukan green marketing, oleh karena itu konsep ini harus disadari oleh setiap pemasar dan dalam perencanaan strategis, perusahaan harus memasukan unsur kepedulian terhadap lingkungan secara terintegrasi. Perencanaan strategis yang berbasis kepedulian lingkungkungan ini bisa dijadikan sebagai salah satu sumber sustainable competitive advantage dalam memenangkan persaingan dimasa yang akan datang.

\section{DAFTAR RUJUKAN}

Bansal, Pratima and Kendall Roth (2000), "Why Companies Go Green: A Model Of Ecologigal Responsiveness", Academy of Management Journal, Vol 43, No 4, pp. 717-736.

Bath, Vasanthakumar N (1993), " Green Marketing Begins With Green Design", The Journal of Business and Industrial Marketing, Vol 8, no 4, pp. 26-31

Crane, Andrew (2000), "Facing The Backflash : Green Marketing and Strategic Reorientation in The 1990s", Journal of Strategic Marketing, Vol 8, pp.277-296.

Karna, Jari, Eric Hansen and Heikki Juslin (2003), "Social Responsibility in Environmental Marketing Planning", European Journal of Marketing, Vol 37, No 5/6, pp. 848-871.

Kotler, Philip (2003), Marketing Management, $11^{\text {th }}$ ed, Englewood Cliffs, NJ: Prentice Hall, Inc.

Mandelson et all (1995), "Using Strategic Alliances To Develop Credible Green Marketing", Journal of Consumer Marketing, Vol 12, issue 2

Mc.Daniel, Stephen W. David H Rylander (1993), "Strategic Green Marketing", Journal of Consumer Marketing, Vol 10, No 3, pp.4-10 